\title{
Anomali Sistem Pemerintahan Presidensial Pasca Amandemen UUD 1945
}

\author{
M. Yasin al-Arif \\ Fakultas Hukum Universitas Islam Indonesia \\ Jln. Tamansiswa No. 158 Yogyakarta \\ yasinfhuii@gmail.com
}

\begin{abstract}
Abstrack
Despite the fact that reformation has been running for 16 years, the idea of strengthening the Presidential System remains a discourse and even worse, it is getting weaker and causing anomalies or irregularities here and there. The first research problem is what is the cause of the anomaly in government presidential system after the amendment of Law of 1945? Second, how to establish an effective government presidential system for the benefit of government in Indonesia? This is a normative research with legal and conceptual approaches. The study discovers that the first anomaly presidential system following the amendment of the 1945 Constitution is influenced by three reasons: (i) a blend of a multiparty system with a presidential system, (ii) the occurrence of a coalition in a presidential system, and (iii) the reduction of presidential powers after the amendment. Second, it requires several steps to establish a presidential system: (i) simplification of political parties; (ii) strengthening the functions and performance of the political parties; (iii) forming a permanent coalition of political parties; (iv) revoking legislative authority of the president; (v) authorizing the presidential veto in the passage of legislation; (vi) depending on leadership style of the president; vii) implementing a district election system.
\end{abstract}

Key words : Presidential system, anomaly, amendment of the 1945 constitution

\begin{abstract}
Abstrack
Meskipun Reformasi telah bergulir selama 16 tahun, namun gagasan penguatan Sistem Presidensial masih tetap menjadi wacana bahkan semakin melemah dan menimbulkan anomali atau penyimpangan. Masalah yang dikaji dalam penelitian ini adalah pertama, apakah penyebab terjadinya anomaly sistem pemerintahan presidensial pasca amandemen Undang Undang Dasar 1945?; Kedua, Bagaimana membentuk sistem pemerintahan presidensial yang efektif untuk kepentingan pemerintahan di Indonesia?. Penelitian ini merupakan penelitian normatif. Pendekatan yang digunakan meliputi pendekatan perundang-undangan dan pendekatan konseptual. Hasil penelitian menunjukkan bahwa pertama, terjadinya anomaly sistem presidensial pasca amandemen UUD 1945 dipengaruhi oleh tiga sebab: (i) perpaduan sistem multipartai dengan sistem presidensial, (ii) terjadinya koalisi dalam sistemp residensial, dan (iii) reduksi kekuasaan presiden pasca amandemen. Kedua, untuk membentuk sistem presidensial maka diperlukan beberapa langkah: (i) penyederhanan partai politik.(ii) penguatan fungsi dan performa partai politik. (iii) membentuk koalisi partai politik yang permanen. (iv) mencabut kewenangan legislasi presiden (v) presiden diberikan hak veto dalam pengesahan undang-undang.(vi) gaya kepemimpinan presiden.(vii) menerapkan sistem permilu distrik.
\end{abstract}

Kata kunci: Sistem presidensial, anomali, amandemen UUD 1945 


\section{Pendahuluan}

Indonesia merupakan negara dengan sistem pemerintahan Presidensial. Hal ini didasarkan pada kesepakatan pendiri bangsa (founding father) dalam sidang Badan Penyelidik Usaha Persiapan Kemerdekaan (BPUPK) pada 29 Mei- 1 Juni dan 10-17 Juli 19451. Dalam hal ini Soepomo memiliki andil yang sangat besar dalam pembentukan pemerintahan Indonesia, karena gagasan yang dikeluarkannya itulah yang kemudian disetujui oleh peserta sidang (meskipun dengan perdebatan yang cukup rumit).

Kemudian, meskipun dalam Pasal 4 ayat (1) UUD 1945 (sebelum amandemen) mengatakan dianutnya sistem pemerintahan presidensial,tetapi sistem yang diterapkan tetap mengandung ciri parlementernya, yaitu dengan adanya MPR yang berstatus sebagai lembaga tertinggi negara, tempat kemana presiden harus tunduk dan bertanggung jawab. ${ }^{2}$ Dengan kata lain sistem presidensial Indonesia tidak begitu tegas karena Presiden tidak dipilih langsung oleh rakyat. Namun, sejak konstitusi diamandemen, tepatnya amandemen ketiga presidensialisme di Indonesia sudah lebih murni.

Dikatakan lebih murni karena Presiden menurut UUD NRI 1945 sebelum amandemen, harus tunduk dan bertanggungjawab kepada MPR yang berwenang mengangkat dan memberhentikannya menurut UUD NRI 1945. ${ }^{3}$ Presiden menurut UUD NRI 1945 sebelum reformasi adalah mandataris MPR yang sewaktu-waktu dapat ditarik kembali oleh MPR sebagaimana mestinya. ${ }^{4}$ Sifat pertanggungjawaban kepada MPR ini justru memperlihatkan adanya unsur parlementer dalam sistem pemerintahan presidensial yang dianut. ${ }^{5}$ Namun setelah diamandemen Presiden dipilih langsung oleh rakyat dan tidak bertanggungjawab lagi kepada MPR sebagai mandataris MPR.

Ditengah membaiknya sistem presidensial dalam pemerintahan Indonesia setelah amandemen UUD 1945 yang ditandai dengan pemilihan presiden secara langsung oleh rakyat dan dibatasinya masa jabatan presiden. Namun dalam praktiknya dengan melihat kewenangan yang diberikan kepada presiden selaku kepala negara dan kepala pemerintahan yang seharusnya otoritas kewenangannya lebih tinggi karena dijamin oleh

${ }^{1}$ Saldi Isra, Pergeseran Fungsi Legislasi, Menguatnya Model Legislasi Parlementer dalam Sistem Presidensial Indonesia, Jakarta: Rajawali Pers, 2010, hlm. 48

${ }^{2}$ Jimly Asshiddiqie, Pengantar Ilmu Hukum Tata Negara, Jakarta: Konstitusi Press, 2006, hlm. 61

3 Jimly Asshiddiqie, "Institute Peradaban dan Gagasan Penguatan Sistem Pemerintahan", disampaikan sebagai orasi ilmiah dalam rangka peluncuran Institute Peradaban di Jakarta, 16 Juli 2012, diakses dari http://www.jimly.com/makalah/namafile/123/SISTEM_PRESIDENTIL.pdf pada hari kamis tanggal 06 Maret 2014. ${ }^{4}$ Ibid.

${ }^{5}$ Ibid. 
sistem pemerintahan presidensial, senyatanya presiden harus kerja lebih ekstra untuk menghadapi gejolak politik di tubuh parlemen. Presiden dalam menjalankan kewenangannya tersandra oleh politikus-politikus di Parlemen.

Realitas saat ini menunjukkan bahwa sistem presidensial tengah dihadapkan pada gejolak politik yang cenderung mengarah pada sistem parlementer. Pasalnya, sistem pemerintahan presidensial selalu dihadapkan pada sistem multipartai yang seharusnya sistem ini lebih sesuai diterapkan pada sistem pemerintahan parlementer. Legitimasi presiden terpilih yang seharusnya menjadi modal politik bagi presiden kerap lumpuh saat dihadapkan pada proses politik di tingkat elite partai. ${ }^{6}$ Cukup menjadi contoh dan pembelajaran bersama bahwa dua kali masa pemerintahan Susilo Bambang Yudhoyono, sebagai presiden pertama yang terpilih melalui pemilihan langsung, belum cukup menguatkan agenda membangun sistem presidensial yang kuat dan berwibawa. ${ }^{7}$

Selain itu, sistem prsidensial juga dihadapkan dengan koalisi partai yang semakin menjadi-jadi. Koalisi politik justru menguat sebagai kebutuhan mendasar dan sulit dihindari. Akibatnya, pembentukan kabinet pemerintahan yang semestinya menjadi wilayah prerogatif presiden cenderung tergerus oleh intervensi politik dari partai-partai yang "berkeringat" dalam kontestasi pemilihan presiden. ${ }^{8}$ Padahal, koalisi itu sesungguhnya ada di dalam sistem parlementer. Kondisi ini menyebabkan Presiden Yudhoyono tidak leluasa untuk membuat keputusannya sendiri. Itu bisa dilihat dari kemunculan sekretariat gabungan (setgab) yang justru menyandera Presiden sebagai ketua setgab. ${ }^{9}$

Dalam sistem presidensial, penyusunan kabinet adalah hak prerogratif ${ }^{10}$ presiden. Namun, teori dan praktik sering kali berbeda jalan. Faktanya, kabinet tidak hanya bersandar pada hak prerogratif, namun juga tergantung pada kompromi dan akomodasi politik. Justru masalah kompromi inilah yang lebih dominan mewarnai penyusunan kabinet. Dominasi tersebut semakin terang-benderang apabila sistem

\footnotetext{
${ }^{6}$ Dilema sistem presidensial, Kompas.com, 26 Agustus 2014.

${ }^{7}$ Ibid.

${ }^{8}$ Ibid.

${ }^{9}$ Koalisi dan Ketidakberdayaan Presiden, Media Indonesia, 11 Maret 2013.
}

${ }^{10}$ Prerogratif secaara kebahasaan berasal dari bahasa Latin praerogativa (dipilih sebagai yang paling dahulu memberi suara), praerogrativus (diminta sebagai yang pertama memberikan suara), praerogare (diminta sebelum meminta yang lain). Sebagai pranata hukum (hukum tata negara), prerogratif berasal dari sistem ketatanegaraan Inggris. Hingga saat ini, pranata prerogratif tetap merupakan salah satu sumber hukum, khususnya sumber hukum tata negara di Kerajaan Inggris. Tidak mudah merumuskan pengertian kekuasaan prerogratif, baik karena sumber historisnya sebagai pranata hukum maupun lingkupnya. Pada saati ini, kekuasaan prerogratif makin banyak dibatasi, baik karena diatur oleh undang-undang atau pembatasan-pembatasan cara melaksanakannya. Ni'matul Huda, Politik Ketatanegaraan Indonesia Kajian terhadap Dinamika Perubahan UUD 1945, Yogyakarta: FH UII Press, 2003, hlm. 104 
presidensial berdiri di atas sistem multi partai. Dalam kondisi demikian, sering terjadi presiden terpilih tidak menguasai mayoritas suara di parlemen. Hadirlah presiden minoritas, lahirlah pemerintahan terbelah. Yaitu pemerintahan yang agenda politik eksekutifnya berseberangan jalan dengan mayoritas aspirasi politik di legislatif. ${ }^{11}$

Selanjutnya, semakin jelas fenomena ketatanegaraan yang ditunjukkan sekarang ini sudah tidak memperlihatkan lagi akan adanya penguatan sistem presidensial. Pasalnya, setelah terpilihnya Jokowi-JK sebagai presiden Republik Indonesia periode 2015-2020, terdapat partai oposisi yang tergabung dalam "koalisi merah putih" secara terang-terangan akan melawan partai pengusung Jokowi-JK. Artinya jika partai pengusung tidak dapat membubarkan koalisi tersebut atau mengajak bergabung dengan partai pihak Jokowi-JK maka presiden yang memegang kendali eksekutif akan lebih tersandera oleh parlemen. Hal ini tentunya sebagai hal yang tidak lazim dalam suatu negara yang menganut sistem pemerintahan presidensial namun dalam praktik ketatanegaraan lebih kepada sistem pemerintahan parlementer. Inilah kiranya anomali yang terjadi pada saat ini dalam tubuh ketatenegaraan negara Indonesia.

\section{Rumusan Masalah}

Berdasarkan uraian di atas, dirumuskan permasalahan sebagai berikut: pertama, Apakah penyebab terjadinya anomali sistem pemerintahan presidensial pasca amandeman UUD 1945? Kedua, Bagaimana membentuk sistem pemerintahan presidensial yang efektif untuk kepentingan pemerintahan di Indonesia?

\section{Tujuan Penelitian}

Adapun tujuan dari penelitian ini adalah pertama, untuk mengetahui penyebab terjadinya anomali sistem pemerintahan presidensial pasca amandemen UUD 1945. Kedua, untuk mengetahui sistem pemerintahan presidensial yang efektif untuk kepentingan pemerintahan di Indonesia. 


\section{Metode Penelitian}

Penelitian ini merupakan penelitian hukum normatif yaitu penelitian yang dilakukan dengan cara meneliti bahan pustaka (library research) atau data sekunder yang terdiri dari: 1) bahan hukum primer yang terdiri dari: a) UUD 1945, b) Naskah Komprehensif perubahan UUD 1945, c) UU No. 42 Tahun 2008 tentang pemilihan presiden; d) UU No. 8 Tahun 2012 tentang pemilihan umum DPR, DPD, DPRD. 2) Bahan hukum sekunder, yang terdiri dari buku-buku literatur, jurnal, hasil penelitian dan karya ilmiah lainnya yang berhubungan dengan penelitian ini. 3) Bahan hukum tersier, yang terdiri dari : a) Kamus Besar Bahasa Indonesia; b) Kamus Inggris Indonesia; c) Kamus Istilah Hukum; d) Ensiklopedia. Metode yang digunakan adalah pendekatan perundang-undangan (statute approach) dan pendekatan konseptual. Adapun metode analisis data yang digunakan adalah analisis kualitatif. Data yang diperoleh dalam penelitian ini akan disajikan dan dioalah secara kualitatif dengan langkah-langkah sebagai berikut: 1) data yang diperoleh dari penelitian diklasifikasikan sesuai dengan permasalahan dalam penelitian;2) hasil kualifikasi data selanjutnya disistematisasikan; dan 3) data yang telah disistematisasikan kemudian dianalisis untuk dijadikan dasar dalam pengambilan keputusan.

\section{Pembahasan dan Hasil Penelitian}

\section{Perpaduan Sistem Multipartai dengan Sistem Presidensial}

Scott Mainwaring dalam penelitiannya mengungkapkan bahwa kombinasi antara presidensialisme dan sistem multi partai yang terpecah belah tampak bertentangan dengan demokrasi yang stabil. Bukti empiris mendukung argumen ini, di dunia terdapat relatif sedikit demokrasi presidensial yang telah bertahan selama 25 tahun atau lebih: Chili, Colombia, Costa Rica, Amerik Serikat, Uruguay dan Venezuela. Dua dari keenam negara ini (Colombia dan Amerika) tetapi memiliki sistem dua partai. Costa Rica pada umumnya pernah memiliki sistem satu partai yang dominan atau sistem dua partai tetap pernah pula memiliki tiga partai. Di Venezuela, dua partai utama telah mendominasi pemilihan umum sejak 1973, dan sistem ini berjalan menurut sistem dua partai, Uruguay memiliki sistem satu partai dominan atau sistem 
dua partai hampir selama sejarah demokrasinya, meskipun sistem ini pernah berubah ke sistem tiga partai (atau dua setengah partai) sejak awal 1970-an.12

Kombinasi antara sistem partai berfraksi dan presidensialisme tidak mendorong stabilitas demokrasi karena kombinasi ini mudah menimbulkan berbagai kesulitan dalam hubungan antara presiden dan kongres. Agar efektif, maka pemerintah harus mampu meneruskan langkah-langkah kebijaksanaan yang sulit dilakukan ketika eksekutif menghadapi oposisi mayoritas di badan legislatif. Sistem parlementer telah melembagakan cara-cara untuk memecahkan masalah ini: dalam banyak hal, perdana menteri dapat mengadakan pemilihan parlemen, dan dalam semua hal atau kasus, parlemen dapat menjatuhkan pemerintah. Pemerintah minoritas memang ada dalam sistem parlementer, tetapi di sebagian besar negara, pemerintah minoritas itu merupakan kekecualian dan tidak bertahan lama. Sistem presidensial tidak memiliki mekanisme seperti itu untuk menghadapi situasi ini, dan konflik antara eksekutif dan legislatif sering kali timbul bila partai-partai yang berbeda menguasai kedua cabang itu. Kemandegan atau konflik yang berkepanjangan dapat menimbulkan akibat yang buruk terhadap stabilitas demokrasi. ${ }^{13}$

Dengan demikian banyaknya partai politik di suatu negara akan lebih sesuai jika dipasangkan dengan sistem Parlementer. Sebab, dalam sistem Parlementer pemegang kepala pemerintahan tidak dikuasakan pada orang yang sama, melainkan kepada orang yang berbeda, yaitu perdana menteri. Seorang perdana menteri biasanya dipilih dari partai politik penguasa yang mempunyai jumlah dukungan paling banyak di antara yang lain.

\section{Dilema Koalisi Presidensial}

Seperti dikemukakan Scott Mainwaring (1993), pemerintahan presidensial dengan sistem kepartaian majemuk merupakan kombinasi yang sulit dan dilematis. Hal itu terjadi jika presiden terpilih tak berasal dari partai politik yang memperoleh kekuatan mayoritas di lembaga legislatif.Untuk mendapat dukungan di lembaga legislatif, presiden berupaya membentuk pemerintahan koalisi dengan merangkul sejumlah partai politik. Cara paling umum yang dilakukan presiden: membagikan

\footnotetext{
${ }^{12}$ Scott Mainwaring, Presidensialisme di Amerika Latin, dalam Arend Lijpart, Sistem Pemerintahan Parlementer dan Presidensial, Ibid., hlm. 119-120

${ }^{13}$ Ibid., hlm. 120
} 
posisi menteri kabinet kepada partai politik yang memberikan dukungan kepada presiden. ${ }^{14}$

Terjadinya fenomena koalisi ini memang tidak terjadi begitu saja, menilik desain sistem pemilu presiden yang berlaku, sulit menghindar dari pembentukan pemerintahan koalisi. Pasal 6A ayat (2) UUD 1945 membuka ruang adanya koalisi partai politik peserta pemilu. Kemudian, UU No. 42 Tahun 2008 tentang pemilihan presiden mengharuskan syarat dukungan paling sedikit 20 persen perolehan kursi di DPR atau 25 persen suara sah nasional dalam pemilu DPR bagi partai politik atau gabungan partai politik untuk mengajukan pasangan calon presiden dan wakil presiden. ${ }^{15}$

\section{Reduksi Kekuasaan Presiden Pasca Amandemen UUD 1945}

Menurut Mahfud MD., kedudukan antara eksekutif dan legislatif adalah sejajar atau sama-sama kuat. ${ }^{16}$ Artinya kedua lembaga tersebut tidak boleh untuk saling intervensi, apalagi kewenangan presiden yang diintervensi. Sebelum amandemen, Presiden mempunyai kewenangan untuk membuat undang-undang yang diatur dalam Pasal 5 ayat (1) UUD 1945, sedangkan DPR hanya sebatas menyetujuinya sesuai dengan Pasal 20 UUD 1945. Waktu itu Indonesia memang belum menganut separation of power sehingga kekuasaan legislasi penuh yang seharusnya dimiliki DPR menjadi tidak terwujud. Bukti lain dapat dilihat dari ketentuan Pasal 19 ayat (1) UUD 1945 yang menyatakan "Susunan Dewan Perwakilan Rakyat ditetapkan dengan undangundang". ${ }^{17}$ Selain itu, sebelum amandemen cheks and balances antar lembaga negara tidak terwujud. Keadaan ini pun berubah setelah terjadinya reformasi konstitusi dari 1999 -- 2002.

Namun demikian, dalam praktiknya sama sekali tidak sesuai dengan tujuan besar dilakukannya reformasi konstitusi tersebut. Hal ini dapat dilihat dari pendapat Ni'matul Huda yang mangatakan bahwa ketika terjadi reformasi konstitusi terhadap UUD 1945, muncul beberapa kesepakatan dasar dalam melakukan perubahan UUD 1945, antara lain mempertegas sistem presidensial. Namun, dalam kenyataannya kesepakatan tersebut tidak ditaati secara konsisten oleh MPR. Pembongkaran

${ }^{14}$ Saldi Isra, Simalakama Koalisi Sistem Presidensial, Opini Kompas, 27 November 2008.

${ }^{15}$ Ibid. 1993, hlm. 83

${ }^{16}$ Mahfud MD, Dasar dan Struktur Ketatanegaraan Indonesia, Universitas Islam Indonesia Press, Yogyakarta,

${ }^{17}$ M. Arsyad Mawardi, Pengawasan Dan Keseimbangan Antara DPR Dan Presiden Dalam Sistem Ketatanegaraan RI, http://journal.uii.ac.id/index.php/jurnal-fakultas-hukum/article/viewFile/70/1823 diakses pada tanggal 4 Maret 2014 pukul $18.50 \mathrm{WIB}$ 
konstruksi presidensialisme dalam UUD 1945 signifikan pada perubahan pertama 1999, kemudian penguatan kelembagaan DPR pada perubahan kedua 2000, bukannya melahirkan keseimbangan kekuasaan antara Presiden dan DPR, tetapi justru menimbulkan ketidakjelasan sistem Presidensial yang ingin dibangun melalui perubahan UUD $1945 .^{18}$

DPR seakan menumpahkan seluruh dendam dan serapahnya karena hampir 32 tahun (1966-1998) dikekang dan berada dibawah komando eksekutif (Presiden). ${ }^{19}$ Lebih jelas yang dimaksud legislative heavy dapat dilihat dari beberapa pasal-pasal dalam UUD NRI 1945 yang mengindikasikan kekuasaan DPR terlalu dominan. Di antaranya yaitu Pasal 11 ayat (1) dan (2), Pasal 13, Pasal 14 ayat (2), Pasal 20 ayat (1) dan Pasal 20 ayat (5). Tidak hanya itu, sangat banyak hak interpelasi yang digunakan legislatif untuk mengkritisi kebijakan pemerintah. Kegiatan untuk meminta keterangan kepada Presiden yang terangkum dalam hak interpelasi DPR tersebut menurut pendapat penulis mengindikasikan adanya subordinate antara DPR dengan Presiden, sehingga seolah-olah terkesan kedudukan DPR berada di atas Presiden.

Selain itu, dalam praktik sering kali dijumpai bahwa hak prerogratif presiden dicekal oleh kekuatan parlemen. Seperti pengangkatan Kepala Polri dan pengangkatan Panglima TNI. Sikap parlemen yang mencampuri pemilihan Kepala Polri dan Panglima TNI, secara legalistik tidak ada yang salah. Wakil rakyat itu memiliki dasar hukum, yaitu sesuai Pasal 11 UU No. 2 Tahun 2002 tentang kepolisian Negara Republik Indonesia (Polri), pengangkatan dan pemberhentian Kepala Polri dilakukan Presiden atas persetujuan DPR. Pasal 13 UU No. 34 Tahun 2004 tentang Tentara Nasional Indonesia (TNI) menyebutkan, Presiden memberhentikan dan mengangkat Panglima TNI setelah mendapatkan persetujuan dari DPR. ${ }^{20}$

Padahal, UUD 1945 termasuk perubahannya tidak mengatur pengangkatan dan pemberhentian Kepala Polri dan Panglima TNI. Bahkan, jika direnungkan, kebijakan pemberhentian dan pengangkatan Kepala Polri dan Panglima TNI itu harus sepersetujuan DPR. Bukan hanya menggerogoti makna Presidensialisme yang digunakan dalam sistem pemerintahan di negeri ini, melainkan tidak sejalan dengan

\footnotetext{
${ }^{18}$ Ni'matul Huda, UUD 1945 dan Gagasan..., Op. Cit., hlm. 283

${ }^{19}$ repository.usu.ac.id/bitstream/123456789/18016/4/Chapter\%20I.pdf diakses pada tanggal 6 Maret 2014 pukul 20.55 WIB

${ }^{20}$ Tri Agung Kristanto, Presidensialisme Masib Tetap Setengah Hati, dalam buku Tinjauan Kompas Menatap Indonesia 2014, Tantangan, Prospek, dan Ekonomi Indonesia, Kompas, Jakarta, 2014, hlm. 11
} 
konstitusi. Pasal 10 UUD 1945 menyatakan Presiden memegang kekuasaan yang tertinggi atas Angkatan Darat, Angkatan Laut, dan Angkatan Udara. ${ }^{21}$

Kerancuan pelaksanaan sistem presidensial dalam pemerintahan di negeri ini, jika mengacu pada UUD 1945 setelah perubahan pertama hingga keempat, kian nyata dengan memperhatikan Pasal 13. Konstitusi hasil perubahan itu menyatakan, presiden berhak mengangkat duta dan konsul. Untuk mengangkat duta presiden diminta memperhatikan pertimbangan dari parlemen. Bahkan, untuk menerima penempatan duta dari negara lain, presiden juga harus memperhatikan pertimbangan dewan. Selain itu, selama ini Presiden terkesan menerima saja pertimbangan, bahkan penolakan yang diajukan parlemen. ${ }^{22}$

Hal tersebut diamini oleh Syamsudin Haris yang menyatakan bahwa masalah yang dihadapi bangsa Indonesia adalah konstitusi hasil amandemen tak sekadar mengadopsi sistem presidensial yang mendekati "murni", tetapi juga kian memperkuat otoritas DPR. Melalui otoritas legislasi yang dimiliki, DPR bahkan memberi hak tunggal bagi diri sendiri guna menyeleksi para pejabat publik, seperti pimpinan Bank Indonesia, Panglima TNI, Kepala Polri, serta pimpinan dan anggota komisi negara yang pembentukannya melalui undang-undang.Otoritas yang seharusnya melekat pada presiden dalam skema presidesialisme menjadi peluang bagi DPR untuk melembagakan "gangguan" terhadap presiden. Desain konstitusi yang semula hendak menyeimbangkan kekuasaan eksekutif-legislatif akhirnya terperangkap pada situasi "sarat DPR". ${ }^{23}$

\section{Redesain Sistem Pemerintahan Presidensial yang Efektif untuk Pemerintahan Indonesia}

Kegaduhan politik beberapa bulan yang terjadi pasca dilantiknya Jokowi-JK sebagai Presiden dan Wakil Presiden Republik Indonesia Periode 2014-2019 memberikan indikasi bahwa masih kuatnya cengkraman politik yang sewaktu-waktu akan menghalangi kebijakan Presiden. Hal ini tak lain dan tak bukan adalah buah dari banyaknya partai yang didukung ketidakstabilan demokrasi di Indonesia. Sehingga hal ini mempengaruhi stabilitas berjalannya sistem Presidensial dan mengubur dalam harapan menguatkan sistem Presidensial. Melihat keadaan yang sangat komplikasi seperti saat ini, tentu tidak dapat dibiarkan begitu saja. Usaha-usaha untuk

\footnotetext{
${ }^{21}$ Ibid., hlm. 12

22Ibid., hlm. 13

${ }^{23}$ Syamsudin Haris, Presidesialisme Cita Rasa Parlementer, Opini Kompas, 28 November 2008.
} 
memulihkan keadaan dan mengusung kembali agenda reformasi untuk menguatkan sistem Presidensial harus tetap digulirkan. Dalam karya ilmiah ini, setidaknya ada tujuh gagasan yang penulis usulkan guna mendesain kembali sistem Presidensial dalam rangka memperbaiki keadaan ketatanegaraan Indonesia dan penguatan sistem Presidensial. Adapun gagasan tersebut adalah:

\section{Penyederhaan Partai Politik}

Mekanisme yang digunakan untuk menyederhanakan partai politik dari multi partai ekstream menuju ke multi partai sederhana atau bahkan untuk mendapatkan dua partai besar yang bersaing dalam pemilu, digunakan mekanisme ambang batas atau sering disebut dengan threshold. Threshold merupakan persyaratan minimal dukungan yang harus diperoleh partai politik untuk mendapatkan perwakilan yang biasanya dilihat dari presentase perolehan suara di pemilu. ${ }^{24}$ Berdasarkan praktik penyelenggaraan pemilu yang dilakukan di Indonesia, dikenal tiga istilah treshold. Yaitu electoral treshold ${ }^{25}$, presidential threshold ${ }^{26}$, parliamentary treshold ${ }^{27}$. Ketiga istilah ini mempunyai arti yang berbeda dalam pelaksanaan pemilu di Indonesia yang diatur berdasarkan peraturan perundang-undangan.

Menurut Kacung Marijan, ada kesalahan dalam memaknai electoral treshold di Indonesia. Sejatinya, yang dimaksud electoral threshold adalah batas minimal suatu partai atau orang untuk memperoleh kursi (wakil) di parlemen. Maksudnya, agar orang atau partai itu mampu menjalankan fungsinya sebagai wakil karena mendapat kekuatan memadai di lembaga perwakilan (di Indonesia dikenal dengan istilah

${ }^{24}$ Hanta Yuda, Presidensialisme..., Op. Cit., hlm. 282

${ }_{25}$ Pasal 39 ayat (3) UU No. 3/1999 mengatur, partai politik bisa mengikuti pemilu berikutnya apabila memiliki sedikitnya 2 persen kursi DPR atau 3 persen kursi DPRD provinsi dan DPRD kabupaten/kota yang tersebar sekurang-kurangnya di $1 \frac{1}{2}$ jumlah provinsi dan $1 / 2$ jumlah kabupaten/kota. Ketentuan ini dicantumkan kembali pada Pasal 143 ayat (1) UU No. 12/2003. Inilah yang disebut electoral threshold, yaitu batas minimal perolehan kursi partai untuk bisa mengikuti pemilu berikutnya (Didik Supriyanto, Treshold dalam Wacana Pemilu, diakses dari www.rumahpemilu.org pada tanggal 10-03-2015 jam 10.57)

${ }^{26}$ Pasal 5 ayat (5) UU No. 23/2003 mengatur, pasangan calon presiden dan wakil presiden diajukan oleh partai atau gabungan partai yang memiliki sedikitnya 15 persen kursi DPR atau 20 persen suara pemilu DPR. Ketentuan ini dinaikkan menjadi 20 persen kursi DPR atau 25 persen suara pemilu DPR oleh Pasal 9 UU No. 42/2008. Inilah yang disebut presidential threshold, yaitu batas minimal perolehan kursi atau suara partai atau koalisi partai agar bisa mengajukan pasangan calon presiden dan wakil presiden

${ }^{27}$ Sementara itu, Pasal 202 ayat (1) UU No. 10/2008 menyatakan bahwa partai politik peserta pemilu harus memenuhi ambang batas perolehan suara minimal 2,5 persen suara nasional (pemilu DPR) untuk mendapatkan kursi DPR. Angka 2,5 persen itu naik menjadi 3,5 persen oleh Pasal 208 UU No. 8/2012. Inilah yang dimaksud parliamentary treshold, yakni batas minimal perolehan suara partai untuk mendapatkan kursi DPR 
parliementary threshold). Namun menurutnya, di Indonesia, threshold dimaknai lain, batas minimal perolehan suara suatu partai untuk bisa mengikuti pemilu berikutnya. ${ }^{28}$

Hal ini diamini oleh Hanta Yuda yang mengatakan bahwa, dalam logika politik pemerintahan, sebenarnya bukan jumlah parpol peserta pemilu yang harus dibatasi, tetapi jumlah ideal kekuatan parpol yang perlu diberdayakan atau dirampingkan di parlemen. ${ }^{29}$ Selain itu, dua kali pemilu menunjukkan, instrumen threshold seperti itu (electoral trheshold) tidak jalan. Pemilu 1999, misalnya, diberlakukan threshold sebesar dua persen. Dari 48 partai, yang lolos threshold hanya enam partai. Faktanya, Pemilu 2004 diikuti 24 partai, dan di antara mereka adalah reinkarnasi sejumlah partai yang tidak lolos threshold Pemilu 1999.30

Lebih lanjut, pengalaman pada pemilu 2004, dengan memberlakukan electoral treshold ternyata tidak efektif untuk menyederhanakan partai politik karena para pemimpin partai yang lolos electoral treshold masih bisa mendirikan partai baru untuk ikut pemilu berikutnya. ${ }^{31}$ Selanjutnya, dengan melihat pengalaman pemilu 2009 memberikan bukti bahwa penerapan parliementary threshold lebih efektif dapat menyederhanakan partai politik. Pada pemilu 2009 dengan besaran ambang batas 2,5 persen dari 38 partai politik peserta pemilu yang lolos mendapatkan kursi di DPR hanya 9 partai politik.

Bagaimana jika ketentuan ambang batas 2,5\% suara nasional itu diterapkan pada Pemilu 1999 dan 2004? Hasilnya juga efektif dalam mengurangi jumlah partai masuk DPR. Pada Pemilu 1999, dari 48 partai peserta pemilu hanya 5 partai politik yang perolehan suaranya memenuhi ambang batas 2,5\%; sedangkan pada Pemilu 2004, dari 24 partai politik peserta pemilu menyisakan 8 partai politik. Jika dibandingkan antara partai politik peserta pemilu dengan partai politik masuk DPR, penerapan ambang batas 2,5\% pada Pemilu 1999 dan 2004 justru lebih berhasil memperkecil jumlah partai politik di DPR daripada Pemilu 2009.32

Selanjutnya, data terbaru dari hasil pemilu 2014 menunjukkan bahwa dari 15 partai politik peserta pemilu 2014 yang lolos mendapatkan kursi di DPR adalah 10 partai. Parliementary threshold yang diterapkan dalam pemilu tersebut diatur dalam

${ }^{28}$ Kacung Marijan, Parpol Baru dan Masalab "Electoral Threshold", diakses dari www.unisosdem.org pada tanggal 10-03-2015

${ }^{29}$ Hanta Yuda, Presidensialisme..., Op. Cit. hlm. 283

${ }^{30}$ Kacung Marijan, Parpol Baru dan..., Loc. Cit.

${ }^{31}$ Hanta Yuda, Presidensialisme..., Op. Cit., hlm. 282-283

${ }^{32}$ Didik Supriyanto dan August Mellaz, Ambang Batas Perwakilan: Pengarub Parliementary Threshold terbadap Penyederhanaan Sistem Kepartaian dan Proporsionalitas Hasil Pemilu, Perludem, 2011.pdf, hlm, 52-53 
UU No. 8 Tahun 2012 bahwa jatah kursi untuk DPR (Nasional) hanya diberikan kepada partai politik yang memenuhi ambang batas perolehan suara sekurangnya $3,5 \%$ dari jumlah suara sah secara nasional. ${ }^{33}$

Semakin besar ambang batas yang dijadikan ketentuan maka akan memberikan hasil yang lebih efektif dalam menyederhanakan partai politik. Hal ini dapat dilihat dari hasil simulasi. Simulasi terhadap hasil Pemilu 1999 menunjukkan, pada besaran $3 \%$, 4\%, dan 5\%, jumlah partai politik di DPR tidak berbeda, yakni 5. Hal yang sama juga terjadi pada hasil Pemilu 2004, di mana penerapan ambang batas 3\%, 4\% dan 5\%, meloloskan 7 partai politik ke DPR. Namun jika simulasi diterapkan pada hasil Pemilu 2009, pada besaran 3\% jumlah partai politik sama dengan yang ada saat ini, yaitu 9. Pada besaran $4 \%$ jumlah partai yang memenuhi ambang batas sebanyak 8 ; dan jika besaran 5\% diterapkan, partai politik yang memenuhi ambang batas sebanyak $6 .^{34}$

Dengan demikian, penerapan parliementary threshold merupakan cara yang tepat untuk penyederhanaan partai politik ekstrem. Parliementary threshold harus dilaksanakan secara konsisten dalam pemilu dan sangat dimungkinkan untuk menaikkan presentase ambang batas. Selain itu, mekanisme implementasi aturan threshold harus lebih ketat. Aturan threshold yang ketat itu, misalnya, partai yang tidak lolos dilarang mengikuti pemilu dua kali berturut-turut. Tidak hanya partai yang dilarang, tetapi elitenya juga dilarang membentuk partai baru. Yang terakhir ini perlu guna menghindari modus metamorfosis seperti terjadi sebelumnya. Melalui pemahaman dan pilihan seperti itu, maka tidak akan dipusingkan munculnya partaipartai baru. Mereka boleh tampil setiap pemilu, tetapi pemilih dan aturan main yang akan menentukan apakah mereka dapat kursi atau tidak. ${ }^{35}$

\section{Membentuk Koalisi Partai Politik yang Permanen}

Tidak dapat dipungkiri bahwa koalisi parpol sulit dihindari dalam koalisi multipartai yang keluaran politiknya cenderung terfragmentasi. Kemunculan koalisi partai politik dalam kondisi multi partai bukanlah sebuah penyimpangan sistem presidensial, tetapi justru sebuah bentuk kompromi untuk stabilitas dan keseimbangan berjalannya sistem politik. ${ }^{36}$ Corak koalisi parpol di Indonesia dalam

\footnotetext{
${ }^{33}$ LSI, Perolehan Kursi Partai dan Peta Koalisi Capres 2014.pdf, hlm.3

${ }^{34}$ Didik Supriyanto dan August Mellaz, Ambang..., Op. Cit., hlm. 53-54

${ }^{35}$ Kacung Marijan, Parpol Baru dan..., Loc. Cit.

${ }^{36}$ Hanta Yuda AR, Presidensialisme ..., Op. Cit., hlm. 29
} 
praktik perpaduan sistem presidensial dan multipartai saat ini bersifat rapuh. Kerapuhan koalisi ini disebabkan beberapa persoalan. ${ }^{37}$ Pertama, komposisi dan jumlah partai dalam koalisi pemerintahan selalu berubah - ubah setiap pergantian pemerintahan. Sistem multipartai merupakan implikasi dari heterogenitas golongan dan kepentingan masyarakat. Komposisi pemerintahan memperoleh kursi legislatif. Komposisi parlemen akan memengaruhi komposisi koalisi dalam pemerintahan.

Kedua, konsekuensi dari pemerintahan koalisi multipartai adalah koalisi pemerintahan tidak menjadikan kedekatan ideologi partai atau common platform sebagai faktor determinan, tetapi lebih didasarkan pada political interest kekuasaan saja. Akibatnya, koalisi pemerintahan akan memiliki daya rekat rendah dan rapuh, sehingga koalisi yang terbangun bukan koalisi ideologis yang solid melainkan koalisi yang bersifat taktis pragmatis. Ketiga, karakteristik institusionalisasi sistem multipartai di Indonesia adalah rendahnya tingkat pelembagaan, terfragmentasinya kekuatan politik di parlemen, dan munculnya koalisi parpol dengan ikatan yang rapuh dan pragmatis, diistilahkan dengan multipartai pragmatis. Istilah ini untuk sekedar menyebutkan kekhasan atau karakteristik khusus dari multipartai di Indonesia.

Partai yang terfragmentasi sehingga menimbulkan rapuhnya koalisi kini tidak hanya melanda era pemerintahan SBY-Budiono, namun kini juga melanda pemerintahan Jokowi-JK. KMP yang menjadi koalisi oposisi menjadi terbelah setelah GOLKAR dan PPP mengalami perpecahan internal pasca dilaksanakannya kongres. GOLKAR yang menjadi motor koalisi KMP dan PPP kini merapat menjadi koalisi pendukung pemerintah. ${ }^{38} \mathrm{Hal}$ ini sebagai bukti bahwa koalisi yang dibangun di Indonesia masih sangat lemah dan tidak permanen.

Menurut Scott Mainwaring, kombinasi antara sistem partai berfraksi dan presidensialisme tidak mendorong stabilitas demokrasi karena kombinasi ini mudah menimbulkan berbagai kesulitan dalam hubungan antara presiden dan kongres. Agar efektif, maka pemerintah harus mampu meneruskan langkah-langkah kebijaksanaan yang sulit dilakukan ketika eksekutif menghadapi oposisi mayoritas di badan legislatif. Setidaknya ada tiga pilihan yang ditawarkan oleh Mainwaring untuk dilakukan Presiden guna menghindari konflik antara eksekutif dengan legislatif, salah

${ }^{37}$ Ibid., hlm. 37

${ }^{38} \mathrm{http}: / /$ www.merdeka.com/politik/golkar-kubu-agung-merapat-ke-jokowi-ini-perbandingan-kmp-vskih.html diakses pada tanggal 23 Maret 2015 pukul 22.40 
satunya yaitu membentuk pemerintah koalisi. Meskipun demikan, pilihan ini juga tidak memberikan harapan baik bagi stabilitas demokrasi. ${ }^{39}$

Oleh karena itu, ada beberapa langkah yang harus dilakukan dalam rangka membentuk koalisi yang kokoh dan mencegah munculnya koalisi politik pragmatis. Pertama, pemilu presiden tidak lagi mengikuti hasil pemilu legislatif. Hal ini penting supaya hasil pemilu legislatif tidak mendikte proses pembentukan koalisi dalam pemilu Presiden. Itu bisa dilakukan secara bersamaan. Sehingga nantinya akan ada pemilu nasional dan pemilu lokal. ${ }^{40}$ Kedua, proses koalisi harus dilakukan sebelum pemilu legislatif dan presiden. Koalisi antar partai dibangun berbasis pada kesamaan platform kebijakan yang diusung oleh koalisi tersebut. Instrumentasi dari koalisi bisa berbentuk mekanisme Stanbus occord untuk pemilu legislatif maupun koalisi untuk mencalonkan kandidat Presiden dan Wakil Presiden. Untuk memperkuat soliditas, koalisi antar partai menyepakati platform kebijakan yang diusung, kelembagaan koalisi, etika dalam koalisi (code of conduct), yang boleh dan tidak boleh berbeda dan reward-punishment. ${ }^{41}$

Ketiga, Wakil Presiden ditunjuk oleh Presiden yang diusung oleh koalisi partai. Hal ini untuk menghindari fenomena "matahari kembar" (mempunyai posisi politik yang sama-sama kuat). ${ }^{42}$ Keempat, koalisi parpol yang kandidatnya menang harus menjadi pendukung pemerintah, sebaliknya koalisi parpol yang kalah mestinya menjadi oposisi. Dengan demikian, hanya ada dua blok koalisi besar di parlemen, yaitu koalisi pendukung pemerintah dan koalisi aposisi. Parlemen akan lebih sederhana dan produktif dengan hanya dua blok koalisi permanen sehingga proses politik pun akan lebih efisien dan efektif. Koalisi ini perlu diatur dan diikat undang-undang agar tidak bisa dicabut atau bubar di tengah jalan dengan mudah. Karena itu, regulasi mengenai koalisi ini perlu dilembagakan dalam sebuah undang-undang. ${ }^{43}$

\section{Gaya Kepemimpinan Presiden}

Karakter kepemimpinan seorang presiden menjadi hal yang tidak dapat diabaikan dalam mewujudkan sistem presidensial yang efektif. Sebab di tangan presiden kekuasaan institusionalitas tertinggi berada. Presiden yang kurang percaya diri, penakut, tidak tegas dan cenderung kompromis akan sering dimainkan oleh kekuatan besar dalam parlemen.

\footnotetext{
${ }^{39}$ Scott Mainwaring, Presidensialisme di Amerika..., Op. Cit., hlm. 120-121

${ }^{40}$ AA GN Ari Dwipayana, Multi Partai..., Op. Cit., hlm. 9

${ }^{41}$ Ibid.

${ }^{42}$ Ibid., hlm. 10

${ }^{43}$ Hanta Yuda AR, Presidensialisme..., Op. Cit., hlm. 290
} 
Selain aspek-aspek institusional melalui penataan ulang desain institusi politik, dalam rangka merancang sistem presidensial yang efektif, juga perlu didukung dengan perbaikan aspek noninstitusional, yaitu personalitas dan gaya kepemimpinan presiden yang kuat (strong president). ${ }^{44}$

Personalitas dan gaya kepemimpinan (personality and leadership style) seorang presiden juga menjadi faktor penting dalam kontruksi pemerintahan presidensialisme yang efektif. Karena itu, diperlukan dukungan nonisntitusional karekteristik personalitas dan gaya kepemimpinan presidenyang tegas, cepat dan tepat dalam mengambil keputusan, memiliki kemampuan lobi dan keterampilan mengolah koalisi, serta memiliki keberanian menggunakan hak prerogratif sesuai konstitusi. ${ }^{45}$

Sikap akomodatif dan kompromis SBY patut menjadi pelajaran berharga bagi Jokowi dan presiden selanjutnya untuk meminimalisir perilaku tersebut dan dapat lebih percaya diri dalam menggunakan hak prerogratifnya tanpa kekhawatiran untuk dihadang oleh manuver politik di parlemen. Selain itu, model transaksional yang digunakan SBY dimana loyalitas dukungan dari partai koalisi ditukar dengan akomodasi posisi dalam kabinet pemerintahan tidak memberikan keuntungan yang besar untuk mendukung kebijakan yang dibuat presiden. Sebab partai koalisi justru seingkali terbelah dalam menyikapi kebijakan presiden. Itu artinya, dukungan dari kubu partai-partai yang berkoalisi terhadap inisiatif kebijakan presiden berubah-ubah dan tidak permanen. Bahkan, partai-partai koalisi seringkali terlibat dalam pusaran konflik dalam proses pengambilan keputusan di parlemen. ${ }^{46}$

Oleh karenanya presiden seharusnya menggunakan modal popular vote dan jumlah kursi yang dikuasai oleh partai presiden di parlemen, untuk mengkonsolidasikan kebijakannya. Di samping itu, presiden juga harus turun tangan langsung dalam memimpin koalisi antar partai, dan memastikan soliditas partai-partai pendukungnya. ${ }^{47}$

Selain itu, jika Presiden bukan pendiri suatu partai politik dan ketika menjadi Presiden hanya "dipinjami" partai tertentu yang mau mendukungnya menjadi Presiden, maka dalam kasus ini, Presiden tidak boleh didekte oleh partai yang mengusungnya menjadi presiden. Presiden harus mengutamakan suara rakyat yang

\footnotetext{
${ }^{44}$ Hanta Yuda AR, Presidensialisme..., Op. Cit., hlm. 304

${ }^{45}$ Ibid.

${ }^{46}$ Ari Dwipayana, Multi Partai..., Op. Cit., hlm. 11

${ }^{47}$ Ibid.
} 
memilihnya dan mengabaikan suara partai politik tertentu yang semata-mata hanya menjadikannya "boneka" untuk mencapai kepentingan partai politik. Sebab ketika menjadi presiden tidak lagi tergantung pada partai politik.

\section{Penutup}

Setelah melakukan penelitian dan menguraikan dua permasalahan dalam penelitian ini, maka dapat ditarik dua kesimpulan sebagai berikut:

Pertama, bahwa terjadinya anomali sistem pemerintahan presidensial pasca amandemen UUD 1945 bukan terjadi begitu saja dan tanpa sebab apapun. Melainkan dipengaruhi oleh tiga faktor determinan yang menimbulkan anomali. Ada pun faktorfaktor tersebut adalah: (i) terjadinya perpaduan antara sistem multi partai dengan sistem presidensial. Perpaduan kedua sistem ini bukanlah pasangan yang serasi untuk mengasilkan sistem presidensial yang efektif. Jika terus dipaksakan maka sistem presidensial akan menjadi lemah dan memperburuk kondisi pemerintahan. (ii) terciptanya koalisi dalam sistem pemerintahan presidensial. Akibat dari diterapkannya sistem multi parti maka menyebabkan lahirnya koalisi antar partai. Terlebih lagi koalisi yang terbentuk adalah koalisi yang rapuh yang hanya ingin mencari kekuasaan. Sehingga koalisi hanya menjadi buah simalakama dalam sistem presidensial. (iii) reduksi kekuasaan presiden pasca amandemen. Lemahnya posisi presiden akibat kewenangan yang dimiliknya direduksi menjadi bukti nyata terjadinya anomali sistem presidendial. Sebab presiden merupakan aktor utama yang memainkan jalannya sistem kepemerintahan. Jika kewenangan yang dimilikinya direduksi maka presiden akan lemah dihadapan parlemen.

Kedua, untuk menciptakan sistem presidensial yang efektif dalam rangka memperbaiki sistem pemerintahan di Indonesia, maka perlu beberapa langkah untuk ditempuh. Di antaranya adalah (i) penyederhanan partai politik. (ii) membentuk koalisi partai politik yang permanen. (iii) gaya kepemimpinan presiden.

\section{Daftar Pustaka}

Asshiddiqie, Jimly, Pengantar Ilmu Hukum Tata Negara, Konstitusi Press, Jakarta, 2006. ,"Institute Peradaban dan Gagasan Penguatan Sistem Pemerintahan", disampaikan sebagai orasi ilmiah dalam rangka peluncuran Institute Peradaban di 
Jakarta, 16 Juli 2012, diakses dari http://www.jimly.com/makalah/ namafile/123/SISTEM_PRESIDENTIL.pdf pada hari kamis tanggal 06 Maret

Budiardjo, Miriam, Dasar-Dasar Ilmu Politik, Gramedia, Jakarta, 1778.

Huda, Ni'matul, Politik Ketatanegaraan Indonesia Kajian terhadap Dinamika Perubahan UUD 1945, FH UII Press, Yogyakarta, 2003.

Hanan, Djayadi, Menakar Presidensialisme Multipartai di Indonesia, Upaya Mencari Format Demokrasi yang Stabil dan Dinamis Dalam Konteks Indonesia, penerjemah: Maufur, MA, Al-Mizan, Bandung, 2014.

Horowitz, Donald L. Perubahan Konstitusi dan Demokrasi di Indonesia, Penerjemah Daryatno, Pustaka Pelajajar, Yogyakarta, 2014.

Haris, Syamsudin, Presidesialisme Cita Rasa Parlementer, Opini Kompas, 28 November 2008.

Isra, Saldi, Pergeseran Fungsi Legislasi, Menguatnya Model Legislasi Parlementer dalam Sistem Presidensial Indonesia, Rajawali Pers, Jakarta, 2010.

, Simalakama Koalisi Sistem Presidensial, Opini Kompas, 27 November 2008.

Indrayana, Denny, Negara Antara Ada dan Tiada, Kompas, Jakarta, 2008.

Kristanto, Tri Agung,Presidensialisme Masih Tetap Setengah Hati, dalam buku Tinjauan Kompas Menatap Indonesia 2014, Tantangan, Prospek, dan Ekonomi Indonesia, Kompas, Jakarta, 2014.

King, Dwight Y,Seandainya Sistem Distrik Berlaku pada Pemilu 1955, Kompas online, 15 Juni 1998, yang dikutip langsung dari tulisan Dr William Liddle ("Proporsional atau Distrik?" Kompas 2 Juni) diakses dari www.seasite.niu.edu

Kacung Marijan, Parpol Baru dan Masalah "Electoral Threshold", diakses dari www.unisosdem.org pada tanggal 10-03-2015

Lijphart, Arend, Sistem Pemerintahan Parlementer dan Presidensial, diterjemahkan oleh Ibrahim R. dkk, Cet.1, PT Grafindo Persada, Jakarta, 1995.

LSI, Perolehan Kursi Partai dan Peta Koalisi Capres 2014.pdf, hlm.

Mahfud MD., Moh. Dasar dan Struktur Ketatanegaraan Indonesia, Universitas Islam Indonesia Press, Yogyakarta, 1993.

Mawardi, M. ArsyadmPengawasan Dan Keseimbangan Antara DPR Dan Presiden Dalam Sistem Ketatanegaraan RI, http://journal.uii.ac.id/index.php/jurnal-fakultashukum/article/viewFile/70/1823 diakses pada 4 Maret 2014 pukul 18.50 WIB

Supriyanto, Didik, Treshold dalam Wacana Pemilu, diakses dari www.rumahpemilu.org pada tanggal 10-03-2015 jam 10.57.

Supriyanto, Didik dan August Mellaz, Ambang Batas Perwakilan: Pengaruh Parliementary Threshold terhadap Penyederhanaan Sistem Kepartaian dan Proporsionalitas Hasil Pemilu, Perludem, 2011.pdf

Yuda AR, Hanta, Presidensialisme Setengah Hati Dari Dilema Ke Kompromi, Gramedia Pustaka Utama, Jakarta, 2010. 